International Journal of Business and Management 3 (3): 09-15, 2019

e-ISSN: 2590-3721

(C) RMP Publications, 2019

DOI: $10.26666 /$ rmp.ijbm.2019.3.2

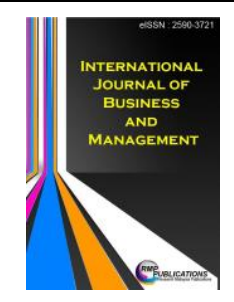

\title{
Culture Shock and Intention to Quit Among Recruits at Basic Army Training Centre in Port Dickson, Malaysia
}

\author{
Faizi Zulkifli, Tey Lian Seng \\ Department of Business Policy \& Strategy, Faculty of Business \& Accountancy, \\ University of Malaya, Malaysia
}

\begin{abstract}
Culture shock and intention to quit both indicate the main variable to the problem face by Malaysia Army (MA) during the Basic Military Training (BMT) conducted. About $10 \%$ to $20 \%$ of the recruits didn't complete the training. MA now are facing a tremendously high dropped out rates of recruits during the training and will make the Army HR Branch in difficult situation to fulfil the vacuum and to maintain its annual end strength requirements. Thus, it is very important to conduct a study the impact of culture shock towards intention to quit. A total of 15 participants participate in this study which consist of 5 dropped out recruits, 5 recruits that passed the initial training/test and 5 instructors. This research was conducted through open-ended questionnaires and face to face interview. The questionnaires and interview questions were developed based on literature review and there were validated by an academician and military expert. The finding of the study revealed the cause this phenomenon happen and the themes that emerged show that culture shock, stress, frustration, fatigue and disorientation has been identified as the main reason of intention to quit among recruits. Due to its small sample size, caution should be made that generalization to the larger population should not be formed from the results of this study. A greater sample would be required to exemplify the general population.
\end{abstract}

Keywords: Culture Shock, Stress, Frustration, Fatigue, Disorientation, Intention to Quit

\section{INTRODUCTION}

A firm or an organization may try to attract qualified applicants and select the best candidates for the organization. It will ensure the competitiveness of the organization in the market place [1]. The initial step in employee recruitment is to draw in people to apply for positions in an organization [2]. The more qualified candidates it draws in, the bigger pool of candidates it can browse, which eventually brings about greater practicality for firm selection mechanisms [3].

Language, symbols, ritual and practices found in the military culture are not the same with the civilian culture [4]. The study had discovered that the British Army's recruit was experiencing culture shock when dealing with numerous demands while undergoing training or transformational process which was needed for them in converting from non-military to military personnel [5]. At a point, the feeling of not blending in to the culture and environment of the military could be sensed by them. Not having sufficient information as what is known as 'knowledge gap' with the detrimental attributes to military culture is one of the reasons that affects military enlistment. Culture shock are prompted among the recruit due to these gaps [6].

By having the intent to quit is really an indicator of real turnover [7]. The theory of planned behaviour indicates that having an intention to quit acts as a predictor to the actual turnover while the behavioural intention acts as a good predictor of real intention [8]. It is more proper and suitable to use the term intention to quit compared to actual turnover due to the fact that actual turnover has numerous external factors which would be deliberated and to foresee the turnover behavior. Besides that, intention to quit is the most direct preceding of turnover intention [9] [10]. In addition, the term turnover as a willing act of leaving an existing occupation or company also concurred that the most direct predictor of actual quitting is turnover intention [11].

\section{LITERATURE REVIEW}

\section{Culture Shock}

The stress faced in the military profession begins from the recruitment stage until the military

Corresponding Author: Tey Lian Seng, Department of Business Policy \& Strategy, Faculty of Business \& Accountancy, University of Malaya. 50630 Kuala Lumpur, Malaysia, E-mail: teyls@um.edu.my 
personnel join the service. The diverse culture exists in the military may cause the personnel to be disoriented. In civil research, stress in military culture is linked to cultural shock [12]. It is due to the unalike working atmosphere and the uniqueness of the military personnel's pressure. The advancement of technology and communication have also created global economy [13]. In this new marketplace, people will have opportunity to choose where they want to work base on their qualification and offer by different other country. When they choose to migrate and work in a different country, they will be exposed and find themselves working in a newly diversified cultured environment. This phenomenon will require organization and individual to cope and meet with the challenges of culture diversity [14].

Previous researchers have identified that culture shock had an impact on individual psychology [15]. Normally the impact of culture shock is a negative impact. The research he conducted aims to explain the effect of culture shock on individual psychology and provide precise answers or resolutions. In this study and related research, the researcher conducted a literature analysis gathering all the related literature. The negative impact might be differed from one person to another. This psychological confusion, emotional discomfort, anxiety and tension usually sets off an immense extent of psychological stress due to experiencing culture shock when unfamiliar behaviours are observed in new cultural environments [16].

Most of the researchers in the field of culture shock used the definition lead of Oberg's in defining culture shock as a base where he defined culture shock as a disease [17]. In line with Oberg's definition, Foster's defined that culture shock as a mental illness which the victims may not know that he is afflicted [18]. Meanwhile, Arensberg and Niehoff defined it as a temporary sickness occurs at the earliest stage when expose to culture shock and easily to recover once the person has the greater familiarization with the new culture [19].

Most of the researchers in the field of culture shock used the definition lead of Oberg's in defining culture shock as a base where he defined culture shock as a disease [17]. In line with Oberg's definition, Foster's defined that culture shock as a mental illness which the victims may not know that he is afflicted [18]. Meanwhile, Arensberg and Niehoff defined it as a temporary sickness occurs at the earliest stage when expose to culture shock and easily to recover once the person has the greater familiarization with the new culture [19].

\section{Concept and Theory of Culture Shock}

The ABC of culture shock theory, the basic theory of culture shock is founded and established by Bochner's [20]. It has been established with all the approaches and processes for dealing with aspects of culture shock. Furthermore, the model explicitly distinguishes three main components of the process mentioned above, namely: Affect (A), Behaviour (B) and Cognitions (C). The ABC will deal with their feelings, behaviour and thinking where it explains how they feel, behave and perceive when going through or affected by culture shock experience.

\section{OBJECTIVE}

To find the cause of intention to quit among recruits at Basic Army Training Centre.

\section{METHODOLOGY}

\section{Procedure}

The letter to get an approval for conducting a research in Basic Army Training Centre was send on the 24 October 2017. A reply letter of approval signed by the Commandant of Basic Army Training Centre on the 27 October 2017 giving the authorization to conduct the research.

\section{Sampling}

This research used a stratified sampling where the participant is already determined. A total of 15 participants participate in this study which consist of 5 dropped out recruits, 5 recruits that passed the initial training/test and 5 instructors. The interviewed was conducted in the big dining hall. The participants were given a set of questions to answer and followed by face to face interview. Before the interview was conducted, all the participants were briefed on what is the objective of the interview. The interview was conducted in Bahasa Malaysia and then translated in English.

\section{Interview Questions}

This research was conducted through questionnaires and interview with 10 recruits and 5 instructors in Basic Army Training Centre in Port Dickson. The questionnaires and interview questions were developed based on LR and there were validated by an academician and military expert. The participants were given a set of questions to answer and followed by face to face interview. 


\section{Data Analysis}

The interview answers were transcribed after the interview was conducted. The analysis was done on the interview to see how the participants were exposed or experienced culture shock and why the participants were thinking to quit the training. A content analysis is conducted to determine the commonalities between the participants. Content analysis is a technique that is used to analyse qualitative data in the study of recorded human communication [21]. Content analysis is "the process of identifying, coding, and categorizing the primary pattern in the data. [22]" As a result, the dominant or key themes had emerged from the analysis.

\section{RESULTS AND DISCUSSION}

Participants comprises of 10 recruits and 5 instructors as mentioned previously. Table 1 is the demographical profile of the participants involved in the study.

Table 1.

Demographical Profile of Participants

\begin{tabular}{|c|c|c|c|c|}
\hline Participant & Gender & Age & $\begin{array}{c}\text { Growing } \\
\text { Up Palace }\end{array}$ & $\begin{array}{c}\text { Place of } \\
\text { Origin }\end{array}$ \\
\hline 1 & Male & 19 & Rural & $\begin{array}{c}\text { East } \\
\text { Malaysia }\end{array}$ \\
\hline 2 & Male & 22 & Rural & $\begin{array}{c}\text { West } \\
\text { Malaysia }\end{array}$ \\
\hline 3 & Male & 23 & Urban & $\begin{array}{c}\text { West } \\
\text { Malaysia }\end{array}$ \\
\hline 4 & Male & 21 & Rural & $\begin{array}{c}\text { East } \\
\text { Malaysia }\end{array}$ \\
\hline 5 & Male & 24 & Urban & $\begin{array}{c}\text { East } \\
\text { Malaysia }\end{array}$ \\
\hline 6 & Male & 23 & Urban & $\begin{array}{c}\text { West } \\
\text { Malaysia }\end{array}$ \\
\hline 7 & Male & 21 & Urban & $\begin{array}{c}\text { West } \\
\text { Malaysia }\end{array}$ \\
\hline 8 & Male & 19 & Urban & $\begin{array}{c}\text { West } \\
\text { Malaysia }\end{array}$ \\
\hline 9 & Male & 22 & Rural & $\begin{array}{c}\text { West } \\
\text { Malaysia }\end{array}$ \\
\hline 10 & Male & 23 & Urban & $\begin{array}{c}\text { West } \\
\text { Malaysia }\end{array}$ \\
\hline Instructor 1 & Male & 33 & NA & $\begin{array}{c}\text { West } \\
\text { Malaysia }\end{array}$ \\
\hline Instructor 2 & Male & 31 & NA & $\begin{array}{c}\text { West } \\
\text { Malaysia }\end{array}$ \\
\hline Instructor 3 & Male & 29 & NA & $\begin{array}{c}\text { East } \\
\text { Malaysia }\end{array}$ \\
\hline Instructor 4 & Male & 27 & NA & $\begin{array}{c}\text { West } \\
\text { Malaysia }\end{array}$ \\
\hline Instructor 5 & Male & 29 & NA & $\begin{array}{c}\text { East } \\
\text { Malaysia }\end{array}$ \\
\hline
\end{tabular}

Table 1 show that all participants were male. The recruits age is between 19 to 24 years old. Most of them came from West Malaysia with the total number of 6 and 4 from East Malaysia. The majority of the recruits were growing up in urban area with the total of 6 and 4 were from the rural area. Meanwhile, the instructors were also male. Their age is between 27 to 33 years old. As mentioned above, the data will be analyzed using simple content analysis. The main goal of using content analysis is to decipher, examine and interpret the meaningful pattern or themes that merged out from the data collected [23]. The proposed three basic steps which are data reduction, data display and conclusion drawing and verification. After conducting a simple content analysis, the key themes emerged and were identified.

\section{Key Themes 1: Culture Shock}

All participants know that the military culture is a different environment that they have to face throughout the training. They described how culture shock influence their emotion and physical towards this military environment. Four participants mentioned that most of them experience culture shock:

"Yes. I experience culture shock when reported to the training center. I found that environment is totally different from the environment that I was used to. At earlier stage of the training, I found that the training is very tough and hard. I do not have enough time to rest".

(Drop2)

"Yes. I experience culture shock where I have to wake up very early in the morning and march to the mosque to perform the prayer. After that I have to prepare for fitness training.

(Drop3)

"I experience it through the military environment and culture where I'm not used to it". The discipline in the military that I feel the main reason that affects me the most during my stay here".

(Drop4)

"I experience culture shock with the military lifestyle and discipline. I only mend my bed in the morning when my mother asked me to do but here you have to do it every day and if you failed to do it you will be punished".

(Drop5)

Five instructor participants have observed that the recruits had experienced culture shock at the earlier stage of their training:

"They experience cultural shock at early stage of training especially when they start the training. They don't expect the tough and hard training especially when it involved physical training. The stage to change their mind set from civilian to military is very 
crucial”,

"They experience culture shock especially when they have to conduct night training and have to get up early the next day to continue the training".

(Instr2)

"Yes. The recruits experience culture shock when the training program starts. Each day they will be introduced to new thing in military working environment. This environment might be different from their previous environment or from their working conditions. Once they can get used with the culture, their life will be easy and can finish the training".

(Instr3)

"The symptoms of experience culture shock among recruit is that they normally always go to the clinic because of health problem. I noticed that their mental and physical resilience is very weak to adopt the military culture.

(Instr4)

"Most of the recruit experience culture shocks and it depends on individual on how they cope with it. Normally they need two to three months to get used to the military culture. One of the roles as an instructor is to guide and advise them on how to deal with culture shock. For those that can manage or cope with this, they might complete the training".

(Instr5)

\section{Key Themes 2: Stress}

Four of the participants acknowledge that their stress level is very high when they experience culture shock. Their feeling and emotion also deteriorated as a result of experiencing culture shock:

"I feel stressed because I have to go through all the tough and hard training. Added to that, the military environment also makes me stressed with the unrest condition".

(Drop1)

"I failed the fitness test because of the stress condition that I have during the test. The instructors forced me to run faster to beat the time for me to pass the test".

(Drop2)

"I feel stressed with the military lifestyle and discipline. I never get used with this environment. I think I am not ready to work with this organization".

(Drop4)

"I feel stressed because I have to pass all the tests in order for me to complete the training. My family expectation also makes me stressed because I have to fulfill their requirement to complete the training and make them proud of me".

(Drop5)

Two of the instructors also mention that they have had an experience with most of the recruit intake when the recruit experience stress due to culture shock:

"One of the indicators that the recruits had experience stress were some of them didn't perform well in the training. Some of them will go to the sick bay or hospital although they were actually not sick".

(Instr2)

"The stress level is different from each individual. Most recruit experience stress because of the new culture that they need to adopt". For those who cannot adapt with the culture, quitting is the best options".

(Instr3)

\section{Key Themes 3: Frustration}

Participants express their frustration in different way during the interview. They found that the military culture makes them frustrated in continuing the training. Three participants felt that their frustration is because training that they are facing demands high expectation and result:

"I felt frustrated because I failed the fitness test that I required to pass in order for me to complete the training. The test is very challenging and required a lot of fitness to pass the test".

(Drop3)

"I have an old injury at my knee because of accident and I keep it secret from everybody. I am very shocked because the training is too tough and hard. I am frustrated because this injury prevents me from passing the training".

(Drop4)

"I feel frustrated when I failed the fitness test 4 times. I tried very hard to pass but I cannot make it. I decided to quit because I found that that military is not a suitable job for me".

(Drop5)

\section{Key Theme 4: Fatigue}

The researcher found that during the interview, there was an indicator that the participants had experienced physical and mental fatigue. While waiting for their turn to be interviewed, the 
researcher found that most of the participants felt asleep while sitting on the chair. The researcher had to call their name at least three times to wake them up for the interview. Although there are two categories of participants mentioned above, the phenomena were the same. The instructors also mentioned that these participants will sleep anywhere when they have the opportunity to rest. It will take them two to three months to adapt with the military environment:

"I increasingly feel a lack of energy to accomplish even the simplest things during the training. I often have headache when I experience culture shock".

(Drop3)

"I was not used to this training environment. There is not enough time for me to rest. Both of my physical and mental were fatigue".

(Stay1)

"I admit that the training program is very packed and I have not enough time to rest. It requires a tough physical and mental strength to go through the training. The training required you to push yourself at the maximum both physical and mental".

(Stay2)

"The military culture required good discipline in all aspects. The drill training was conducted at the parade square where the heat is very hot. It challenges my physical and mental resilience where I need to do both activity during the psychical training and drill”.

(Stay3)

\section{Key Themes 5: Disorientation}

Four participants expressed their disorientation due to culture shock through confusion. This phenomenon leads them to confusion such as their future in the service and their ability to make decision about their future undertaking:

"I feel confused with the military culture and the chain of command in the military organization".

(Drop2)

"I feel confused whether to accept military as my choice of career after I experience culture shock and after I failed the fitness test".

(Drop3)

"There was one occasion when I was trying to prepare myself for the training, but constantly my thoughts wandered off and I found myself staring at the wall and doing something else".

(Drop4)

"After undergoing the training, I was confused and doubtful whether I can complete the training”.

(Drop5)

All together there are five key factors emerged from this study. Firstly, is culture shock where most of the recruits' experience culture shock for the beginning two months of the training. They were cannot adopt with the new military environment and culture. Military environment and culture requires and demands more physical and psychological conditions compare to most civilian [24].

Besides that, the result also revealed the presence of stress among recruits due to culture shock that lead to intention to quit. Individuals are going to be highly stressed and experience changes in mood or behaviour when going through the transition phase from non-military to military life [25]. This high level of stress occurs throughout the training due to a rigorous mental and physical training they face. Basically, the recruits level of stress fluctuate at its highest point during the first week of their training [26].

Furthermore, frustration is also a result of unmet expectation. It is discovered that the likelihood to resign from the organization is very high when the employee exhibits a high level of frustration [27]. Unmet expectation happens when the initial expectations at work are not fulfilled. Unfulfilled expectations are believed to be a crucial factor influencing new recruits to leave at the beginning phase in the military [28].

Apart from frustration, the study also revealed physical and mental fatigue as the cause of cultural shock. During the training, recruits easily feel fatigue. Physical fatigue involves the use of maximum muscle capacity to perform heavy exercise physical work. When individuals work with heavy physical activity, muscles will work until they become exhausted [29]. Mental fatigue can be described as overload as well as underload of work. Both qualitative and quantitative terms can be used for overload. Qualitatively, too much innovation and complexity describe overload meanwhile in quantitative term, overload means working for long hours or too frequent. Underload describes tasks that are to mundane or otherwise recurring [30].

Lastly, disorientation occurred when the recruit is unaware of the surrounding environment, particularly in the military environment, which varies from its prior environment. The indicators of cultural shock is the deficiency of orientation on their personal life which causes their prospects for future life and career in a state of disorientation [31]. They were confused, suffered increased pressure and uncertainty in the future. Employees will 
encounter environmental disorientation when their working conditions are disapproving or poor [32]. In this case, it involved with the hard and tough training they need to comply every day for the next six month durations. Table 2 show the summary of the key themes.

Table 2.

Summary of Key Themes

\begin{tabular}{|c|c|c|c|c|c|}
\hline \multirow{2}{*}{ Participant } & \multicolumn{5}{|c|}{ Items } \\
\cline { 2 - 6 } & $\begin{array}{c}\text { Culture } \\
\text { Shock }\end{array}$ & Stress & Frustration & Fatigue & Disorientation \\
\hline Stay 1 & - & - & - & $\sqrt{ }$ & - \\
\hline Stay 2 & - & - & - & $\sqrt{ }$ & - \\
\hline Stay 3 & - & - & - & $\sqrt{ }$ & - \\
\hline Stay 4 & - & - & - & - & - \\
\hline Stay 5 & - & - & - & - & - \\
\hline Drop 1 & - & $\sqrt{ }$ & - & - & - \\
\hline Drop 2 & $\sqrt{ }$ & $\sqrt{ }$ & - & - & $\sqrt{ }$ \\
\hline Drop 3 & $\sqrt{ }$ & & $\sqrt{ }$ & $\sqrt{ }$ & $\sqrt{ }$ \\
\hline Drop 4 & $\sqrt{ }$ & $\sqrt{ }$ & $\sqrt{ }$ & - & $\sqrt{ }$ \\
\hline Drop 5 & $\sqrt{ }$ & $\sqrt{ }$ & $\sqrt{ }$ & - & $\sqrt{ }$ \\
\hline Instructor 1 & $\sqrt{ }$ & - & - & - & - \\
\hline Instructor 2 & $\sqrt{ }$ & $\sqrt{ }$ & - & - & - \\
\hline Instructor 3 & $\sqrt{ }$ & $\sqrt{ }$ & - & - & - \\
\hline Instructor 4 & $\sqrt{ }$ & - & - & - & - \\
\hline Instructor 5 & $\sqrt{ }$ & - & - & - & - \\
\hline
\end{tabular}

The summary of the Table 2 explained clearly that the 5 factors influence the recruit's intention to quit the training.

\section{CONCLUSION}

The results of this study are inherent in nature but can provide some insights that can be considered as interfering elements of the intention to stop recruiting issues in the military context. These findings are not a prediction of the actual study to be carried out but the data will be useful in the development of a research framework and study hypothesis. The findings also can serve as a basis for studying how to reduce the intention to quit so that so that money and time is not wasted.

There are several limitations to this study. The research involved only male respondents, so researchers who restrict their study to just one gender should be questioned as to whether the finding could be generalized to the other gender [33]. Recruitment of female military personnel in the Malaysian Army is very limited due to limited female personnel positions. This study is also limited to only active staff and cannot be generalized to volunteers in the army because they have different work - related issues than those in active duty [34].

\section{REFERENCES:}

[1] Williamson, I. O., Lepak, D. P., \& King, J. (2003). The effect of company recruitment web siteorientation on individuals' perceptions of organizational attractiveness. Journal of Vocational Behavior, 63(2), 242-263.

[2] Barber, A. E. (1998). Recruiting employees: Individual and organizational perspectives. Thousand Oaks, CA: Sage Publications.

[3] Boudreau, J.W. \& Rynes, S.L. (1985). Role of recruitment in staffing utility analysis. Journal of Applied Psychology,12, 354366. Review, 77,52-63.

[4] Soeters J.L., Winslow D.J. \& Weibull A. (2006). Military culture. Hand- book of the Sociology of the Military: Springer, 23754.

[5] Kiernan, Matt, Repper, Julie \& Arthur, Antony (2015) Why do they fail? A qualitative follow up study of 1000 recruits to the British Army Infantry to understand high levels of attrition.: A Journal of Prevention, Assessment \& Rehabilitation, 52 (4). 921-934.

[6] Megan, S \& Lindy, H (2014). Factors influencing military recruitment in South Africa: the voices of Cape Town high school learners, African Security Review, 23(2), 102-116.

[7] Mohd Makhbul, Z., Mohd Radzuan, R., \& Mohamad Hasun, F. (2011). What made they go. Journal of Global Management, 1(1).

[8] Ajen, I. (1991). The theory of planned behaviour. Organizational Behaviour and Human Decision Processes. 50, 179-211.

[9] Bluedorn, A.C. (1982). A unified model of turnover from organizations. Human Relations, 35(2), 135-153.

[10] Price, J. L., \& Mueller, C. W. (1981). A causal model of turnover for nurses. Academy of Management Journal, 24, 543565.

[11] Alexander, Lichtenstein, Oh, \& Ullman. (1998). A Causal Model Of Voluntary Turnover Among Nursing Personnel In Long- Term Psychiatric Settings. Research in Nursing and Health,21(5), 415-427.

[12] Azari, Dandeker \& Greenberg, N. (2010). Cultural Stress: How Interactions with and among Foreign Populations Affect Military Personnel. Armed Forces \& Society, 36 (4), 585-603.

[13] Friedman, T. L. (2006). The world is flat: A brief history of the twenty-first century (Rev. ed.). New York: Farrar, Straus and Giroux.

[14] Earley, P. C., Ang, S., \& Tan, J. (2006). CQ: Developing cultural intelligence at work.Stanford, CA:Stanford Business Books. 
[15] Junzi, Xa. (2009). Analysis of impact of acculturative stress on individual psychology. International Journal of Psychological Studies, 1, 97-101.

[16] Eschbach, D., Parker, G. \& Stoeberl, P. (2001). American repatriate employees' retrospective assessments of the effects of cross-cultural training on their adaptation to international assignments. The International Journal of Human Resources Management, 12 (2), 270-287.

[17] Oberg, K. (1960). Culture shock: Adjustment to new cultural environments. Practical Anthropology, 7, 177-182.

[18] Foster,G.(1962). Traditional culture. New York: Harper \& Row.

[19] Arensberg, C. M., \& Niehoff, A. H. (1964). Introducing social change. Chicago: Aldine.

[20] Bochner, S. (2003). Culture Shock Due to Contact with Unfamiliar Cultures. Online Readings in Psychology and Culture, 8(1),7.

[21] Babbie, E. (2007). The practice of social research. $11^{\text {th }}$ edition. Belmont: Thomson Wadsworth.

[22] Cavana, R. Y., Delahaye, B. L. \& Sekaran, U. (2001) Applied business research: Qualitative and quantitative methods, Queensland, Australia, John Wiley \& Sons.

[23] Malhotra, N.K.(2007). Marketing Research: An Applied Orientation. Upper Saddle River: Pearson Prentice Hall

[24] Krueger, G. P. (2001). Military psychology: United States. International Encyclopaedia of the Social \& Behavioural Sciences. 9868-9873.

[25] Gold, M.A \& Friedman, S.B (2000). Cadet basic training: An ethnographic study of stress and coping. Military Medicine, 165,147-5.

[26] Clemons, E.P. (1996) Monitoring anxiety levels and coping skills among military recruits. Military Medicine, 161, 18-21.

[27] Storms, Philip L \& Spector, Paul E. (2011). Relationships of organizational frustration with reported behavioural reactions: The moderating effect of locus of control. Journal of Occupational Psychology, 60(3), 227-234.

[28] Griffeth, R. W., \& Hom, P. W. (2001). Retaining Valued Employees. Thousand Oaks: Sage.

[29] Åstrand P-O \& Rodahl K (1986). Textbook of work physiology. Physiological bases of exercise. New York: McGraw-Hill.

[30] Frankenhaeuser M, \& Johansson G. (1981). On the psychophysiological consequences of under stimulation and over stimulation. In: Levi L, ed. Society, stress and disease. London: Oxford University Press: 81- 89.

[31] Melich, J.S. (1997). The post-communist mind - how real a phenomenon? Sociopsychological legacies of communist rule. YASF Student Cultural Centre, 20-41.

[32] Milman, A. (2002). Hourly employee retention in the attraction industry: research from small and medium size facilities in Orlando, Florida. Journal of Leisure Property, 2, 40-51.

[33] Helgeson, V. S. (2002). The Psychology of Gender. Upper Saddle River, New Jersey: Prentice Hall.

[34] Sanchez, R. P., Bray, R. M., Vincus, A. A., \& Bann, C. M. (2004). Predictor of Job Satisfaction among Active Duty and Reserve/Guard Personnel in the U.S Military. Military Psychology, 16(1), 19-35 